\title{
PD-L1 Polymorphism Can Predict Clinical Outcome of Brazilian Non- Small Cell Lung Cancer Patients After Postoperative Adjuvant Treatment
}

\section{Juliana Machado-Rugolo}

Health Technology Assessment Center, Clinical Hospital (HCFMB) Medical School of Sao Paulo State University (UNESP)

Tabatha Gutierrez Prieto

Universidade de Sao Paulo Faculdade de Medicina https://orcid.org/0000-0002-2615-6922

Alexandre Todorovic Fabro

Department of Pathology and Legal Medicine, Riberão Preto School of Medicine, University of Sao Paulo

Edwin Roger Parras Cuentas

Department of Translational Molecular Pathology, The Universyty of Texas MD Anderson Cancer Center

Vanessa Karen Sá

ACCamargo Cancer Center

Camila Machado Baldavira

Universidade de Sao Paulo Faculdade de Medicina

\section{Claudia Aparecida Rainho}

Instituto de biociências da Universidade do Estado de Sao Paulo (UNESP) Botucatu

Erick C. Castelli

Faculdade de Medicina da Universidade do Estado de Sao Paulo (UNESP) Botucatu

Cecilia Farhat

Universidade de Sao Paulo Faculdade de Medicina

Teresa Yae Takagaki

Universidade de Sao Paulo Instituto do Coracao

Maria Aparecida Nagai

Universidade de Sao Paulo Instituto do Cancer do Estado de Sao Paulo

Vera Luiza Capelozzi ( $\nabla$ vera.capelozzi@fm.usp.br)

https://orcid.org/0000-0001-9732-5853

\section{Research article}

Keywords: Non-small Cell Lung Cancer (NSCLC), Single-nucleotide Polymorphism (SNP), PD-L1, Next-generation Sequencing

Posted Date: July 6th, 2020

DOI: https://doi.org/10.21203/rs.3.rs-40075/v1

License: (1) This work is licensed under a Creative Commons Attribution 4.0 International License. Read Full License 


\section{Abstract}

\section{Background}

Although the incidence and mortality of non-small cell lung cancer (NSCLC) remains high with poor prognosis, programmed death-1 (PD1) and programmed death-ligand 1 (PD-L1) pathway are promising prognostic and predictive biomarker of NSCLC. The polymorphisms on $P D-L 1$ gene may be associated with their protein expressions and affect the adjuvant treatment and outcome of NSCLC patients. The goal of this study was to evaluate the clinicopathologic values of PD-L1 expression and single-nucleotide polymorphisms (SNPS) in the PD-L1 gene in lung adenocarcinoma (ADC), squamous cell carcinoma (SqCC), and large cell carcinoma (LCC).

\section{Methods}

The 70 NSCLC samples consisted of 33 samples of ADC, 24 of SqCC and 13 of LCC. All tissue microarray paraffin blocks were used for PD-L1 multiplex immunofluorescence assays with Cell Signaling E1L3N clone. Fifteen polymorphisms in the PD-L1 gene were investigated by deep targeted sequencing.

\section{Results}

The PD-L1 expression was higher in ADC than in SqCC and LCC. Three polymorphisms rs4742098, rs4143815, and rs7041009 were significantly associated with tumor recurrence $(P=0.01 ; P=0.05 ; P=0.02$, respectively). According to the recurrence of the disease, carriers of the $\mathrm{G}$ allele were less likely to relapse $(P=0.01)$ compared to the homozygous AA genotype for rs 4742098 . As in rs 4143815 , individuals with the $C$ allele were also less likely to relapse $(P=0.05)$. As for rs 7041009 , individuals with $A G$ or $\mathrm{GG}$ genotypes were more likely to relapse. The $\mathrm{G}$ allele of rs7041009 also showed a significant correlation with age, younger patients, $16(41.0 \%)$ and status, among 11 (39.3\%) compared to carriers of the A allele ( $P=0.02$ and $P<0.01$, respectively). The rs7041009 AG genotype was inversely associated with E1L3N clone PD-L1 labeling in NSCLCs but did not reach statistical significance. Kaplan-Meier survival curves showed that the prognosis of patients with NSCLC was strongly dependent on the alternative allele G (genotype AG or GG) of rs 4742098 , alternative allele C (genotype CG or CC) of rs4143815 and individuals with GG genotype of rs7041009 ( $P=0.02 ; P=0.05$ and $P<0.01$, respectively). Multivariate analysis by the Cox Regression model showed genotype GG of rs7041009 independently associated with cancer recurrence and patients without adjuvant radiotherapy (hazard ratio $[\mathrm{HR}]=7.59,95 \%$ confidence interval $[\mathrm{Cl}]=1.06-54.03$, and $\mathrm{HR}=9.24, \mathrm{Cl}=1.13-75.16$ ).

\section{Conclusions}

PD-L 1 rs7041009 GG polymorphisms may be useful for the prediction of clinical outcome of radiotherapy in NSCLC. Further studies are needed to confirm our findings and to understand the role of PD-L1 in the radiotherapy outcome of NSCLC patients.

\section{Background}

Lung cancer is still the leading cause of cancer-related mortality worldwide with a poor prognosis [1]. Most of the patients with non-small cell lung cancer (NSCLC), which represents $85 \%$ of all patients with lung cancer, are diagnosed at advanced stages or are presenting with recurrent disease after initial locoregional treatment [2]. Over the past few decades, conventional chemotherapy, mainly platinum-based, was the only therapeutic option for those not eligible for radical intent treatment, with limited efficacy and very few long-term survivors- 5year overall survival $<15 \%$, and highlighting the fact that therapeutic options beyond first-line treatment remained limited for patients [3].

The blockade of immune checkpoints has recently been applied as an antitumor immune therapy. Moreover, various immune checkpoint molecules related to tumor immune evasion have recently been identified. Tumor cells express the programmed death-1-ligand 1 (PD-L1) as an adaptive, resistant mechanism to suppress the inhibitory receptor, namely programmed cell death-1 (PD-1) in order to evade host immunosurveillance [4]. Because PD-L1 up-regulation by tumor cells can protect tumor cells from antitumor immune response, blockade of PD-L1/ PD-1 interactions have been recently selected for antitumor immune therapy [5]. Furthermore, Agents targeting the PD-1/PD-L1 signaling have shown promising response in NSCLC treatment. PD-L1 protein expression may be predictive for a blockade of the PDL1/PD-1 interactions [6]. However, this biomarker is not sufficiently robust and demonstrates many challenges.

In this context, some studies demonstrated that patients with more than $50 \%$ PD-L1 positive tumor cells are non-responders to anti-PD1/PD-L1 treatment. In contrast, others shown that patients whose tumors do not express PD-L1 are good responders [7-9]. To explain the conflict that affects the PD-L1 expression, some studies have considered that the heterogeneity of axis expression and response to PD1/PD-L1 treatment in NSCLC depends on alterations in other factors, such as more precise methods to investigate immune evasion 
mechanisms and immune microenvironment, as well as immune checkpoint genomic profile and genetic variants regarding $P D-L 1$ gene [10-13].

Genetic variants might affect the normal process of gene activation and transcriptional initiation, hence influence the quantity of mRNA and encoded protein [14]. Thus, several studies investigated the association between genetic polymorphisms of $P D-1$ and $P D-L 1$ genes and the risk of various cancers, but the finding was not completely elucidated yet [15].

A recently reported study suggested that $P D-L 1$ polymorphism may predict chemotherapy response and survival of advanced stage NSCLC patients after first-line paclitaxel-cisplatin [16]. The occurrence of polymorphisms in genes that are involved in immune checkpoints may affect the antitumor immune activity, thereby prognosis of patients with early stage NSCLC after surgery.

Therefore, in this study, we hypothesized that $P D-L 1$ polymorphisms could modify the function of the immune checkpoint. To test our hypothesis, fifteen PD-L 1 single-nucleotide polymorphisms (SNPs): rs76805387, rs4742098, rs47946526, rs10217310, rs7864231, rs41280725, rs573692330, rs1011769981, rs41280723, rs138135676, rs4143815, rs2297136, rs148242519, rs41303227 and rs7041009 were correlated to PD-L1 protein expression level and clinicopathological characteristics, including prognosis of NSCLC patients undergoing surgical resection, glimpsing the impact of SNPs on overall survival (OS).

\section{Methods}

\subsection{Patient Samples}

We obtained archival formalin-fixed paraffin-embedded histologic tumor sections from 164 patients diagnosed with NSCLC who had undergone surgical resection between January 1, 1995, and December 31, 2015, and who had not received neoadjuvant therapy. Patients had been treated at the Hospital das Clinicas of the State University of São Paulo Medical School (HC-FMUSP), the Heart Institute of the University of São Paulo (INCOR), the Cancer Institute of São Paulo (ICESP), and the A.C. Camargo Cancer Center, São Paulo, Brazil.

Samples were histologically reviewed by pathologists before nucleic acid extraction in order to select samples with at least $30 \%$ of lung cancer cells. We extracted DNA from snapped frozen samples obtained from 70 of the 164 patients in our study. According to the pathological reports, the samples included adenocarcinoma (ADC, $n=33$ ), squamous cell carcinoma $(S q C C, n=24)$, and large cell carcinoma ( $L C C, n=13)$. The clinical information and basic characteristics of the patients were recorded by physicians.

\subsection{Dna Extraction}

Genomic DNA (gDNA) was extracted from frozen NSCLC tissue using the QIAamp DNA Mini Kit (Qiagen) following the manufacturer's recommendations. DNAs were quantified by Qubit (Life Technologies) and integrity was assessed by BioAnalyzer 2100 (Agilent Technologies).

\subsection{Sequencing And Data Analysis}

The PD-L 1(CD274) gene (ID: 17635) was investigated by deep targeted sequencing using TruSeq Custom Amplicon Panel v1.5kit (TSCAP, Illumina) and the MiSeq platform (Illumina) was conducted on 70 tumor tissue samples. DNA libraries was performed according to the manufacturer's instructions consisting of 150 bp paired-end reads in 300 cycles. The panel includes the complete region of gene including rs76805387, rs4742098, rs47946526, rs10217310, rs7864231, rs41280725, rs573692330, rs1011769981, rs41280723, rs138135676, rs4143815, rs2297136, rs148242519, rs41303227 and rs7041009 short genetic variants.

NGS data analysis was performed on Molecular Genetics and Bioinformatics Laboratory, Experimental Research Unit (UNIPEX) at Medical School of São Paulo State University (UNESP). Sequencing quality was assessed by FastQC. Reads were aligned to the human genome (hg19, GRCh37) with BWA software and SAMtools was used to convert the alignment results to BAM format [17]. Mapped reads underwent variant calling for SNP with GATK command line tools, including HaplotypeCaller, SelectVariants, and VariantFiltration programs using default parameters. After calling step, the variants were annotated using the VEP [18] software. Coverage depth was a priori settled up at 100x. Filtered retained variants had to have $>10$ reads of position depth (PD) and/or $>6$ reads of allele depth (AD) and/or an AD/PD ratio of $>0.05$ and/or a population frequency higher than $1 \%$ (popfreq_all $>0.01$ ). 


\subsection{Multiplex Immunofluorescence Staining}

Multiplex immunofluorescence ( $\mathrm{mIF}$ ) staining was performed using similar methods that have been previously described and validated $[19,20]$. Four micrometer-thickness consecutive TMA sections were stained using an automated staining system (BOND-RX; Leica Biosystems, Buffalo Grove, IL) to characterize PD-L1 (clone E1L3N, dilution 1:100; Cell Signaling Technology, Danvers, MA). The marker was stained in sequence using their respective fluorophore containing in the Opal 7 kit (catalogue \#NEL797001KT; Akoya Biosciences/PerkinElmer, Waltham, MA) after completely validation using immunofluoresce (IF) to obtain an uniform, specific, and correct signal across all channel to be well balanced staining pattern during the multiplex staining $[19,20]$. The correct signal from the fluorophores, were also defined and optimized between 10 to 30 counts of intensity, to maintain a good balance and similar thresholds of intensity across all the antibodies.

In parallel, to detect possible variations in staining and optimal separation of the signal, positive and negative (auto- florescence) controls were included during the staining to make sure, especial with the internal positive control that all the antibodies are working together. Autofluorescence controls with an expected spectral of $488 \mathrm{~nm}$ will be able to accurate remove the auto-fluorescence from all the label signals during the analysis process. The stained slides were scanned using a multispectral microscope, Vectra Polaris 3.0 imaging system (Akoya Biosciences/PerkinElmer PerkinElmer), under fluorescence conditions.

\subsection{Multiplex Immunofluorescence Quantitation}

Multispectral images of tumor sections from each core were analyzed with inForm 2.2.1 (Akoya/PerkinElmer) software Individual cells, which were defined by nuclei staining and identified by the InForm cell segmentation tool, were subjected to a phenotyping patternrecognition learning algorithm to characterize co-localization of the various cell populations using panel labeling [20, 21]. The panel labeling was as follows: Malignant cells, (MCs) with the AE1/AE3 + marker, including those with and without PD-L1 expression (AE1/AE3 + PD-L1 + and AE1/AE3 + PD-L1-, respectively).

The individual cell phenotype report produced by the InForm software was processed using Excel 2010 (Microsoft. Houston, TX), and a final summary of the data, which contained the median of each individual phenotype (given as number of cells $/ \mathrm{mm}^{2}$ ) and the percentage of macrophages and MCs expressing PD-L1, was created for statistical analysis. If the percentage of MCs or macrophages expressing PDL1was greater than the median value, the PD-L1 expression was considered positive. If the percentage of macrophages or MCs expressing PD-L1 was lower than or equal to the median, the PD-L1 expression was considered negative.

\subsection{Statistical Analysis}

The statistical analysis of allelic and genotypic frequencies of PD-L1 polymorphisms in NSCLC group was calculated by Hardy Weinberg equilibrium ([1 _ $(\mathrm{hC} 2 \mathrm{H})] / 2 \mathrm{~N}$, where "h" represents as heterozygous genotype, " $\mathrm{H}$ " for homozygous and " $\mathrm{N}$ " represents the number of samples. Associations between polymorphisms, PD-L1 protein expression, and clinicopathological parameters of NSCLC patients were investigated by Fisher exact test. Prognostic value was assessed by survival analysis using the Kaplan-Meier method with the log-rank test for statistical significance. In addition, we used Cox's proportional hazards regression models were used in a multivariate analysis to test the association of the SNPs with OS. OS was defined as the time from curative surgery to the date of death or censored on the last date known to be alive. The statistical software programs IBM SPSS (version 22; Armonk, NY, USA) was used to perform all analyses. Differences were considered statistically significant at $P<0.05$.

\section{Results}

\subsection{Clinicopathologic characteristics}

The clinical characteristics of the patients in our cohort are summarized in Table 1, stratified by histologic types. Of 70 patients included in the study, 24 (32.9\%) had SqCC, 13 (17.8\%) had LCC, and 33 (45.2\%) had ADC. Among 24 SqCC, 9 (22.5\%) were more frequent in males, while the $33 \mathrm{ADC}$ cases were equally distributed among the genders 10 (25.0\%). All histological types were more frequent in patients with 63 years or younger. Regarding the tobacco smoking history, 8 (30.8\%) occurred both in patients with ADC and patients with SqCC and 3 (11.5\%) in patients with LCC. All the histological subtypes presented more cases with an advanced stage of disease (9 cases to ADC, 6 cases to SqCC, and 4 cases to LCC). Most of the patients do not receive chemotherapy (12 cases to ADC, 8 cases to SqCC, and 6 cases to LCC) or radiation therapy (18 cases to ADC,10 cases to SqCC and LCC) as adjuvant treatment. According to PD-L1 protein expression in

Page $4 / 20$ 
malignant cells, LCC with 7 (13.2\%) presented more relevant expression, above the median, when compared to other histological subtypes. The median follow-up of the patients was 66 (12-144) months. Follow-up information about survival was missing for 45 patients, 15 (20.5\%) patients died after disease progression. In all analyzes, there were no significant differences between the histological types $(P>$ $0.05)$. 
Table 1

Demographic and clinicopathological characteristics of 70 patients with NSCLC.

\begin{tabular}{|c|c|c|c|c|}
\hline \multicolumn{4}{|c|}{ Histological Subtypes } & \multirow{2}{*}{$\begin{array}{l}P \\
\text { value }\end{array}$} \\
\hline Characteristics & $\begin{array}{l}\text { Adenocarcinoma } \\
(\mathrm{N}=33)\end{array}$ & $\begin{array}{l}\text { Squamous cell carcinoma } \\
(\mathrm{N}=24)\end{array}$ & $\begin{array}{l}\text { Large cell carcinoma } \\
(\mathrm{N}=13)\end{array}$ & \\
\hline \multicolumn{5}{|l|}{${ }^{\mathrm{a}}$ Gender } \\
\hline Male & $10(25.0 \%)$ & $9(22.5 \%)$ & $5(12.5 \%)$ & \multirow[t]{2}{*}{0.21} \\
\hline Female & $10(25.0 \%)$ & $2(5.0 \%)$ & $4(10.0 \%)$ & \\
\hline \multicolumn{5}{|l|}{ a Age (years) } \\
\hline$\leq 63$ & $11(28.2 \%)$ & $6(15.4 \%)$ & $6(15.4 \%)$ & \multirow[t]{2}{*}{0.93} \\
\hline$\geq 63$ & $7(17.9 \%)$ & $5(12.8 \%)$ & $4(10.3 \%)$ & \\
\hline \multicolumn{5}{|l|}{ aSmoke Status } \\
\hline Yes & $8(30.8 \%)$ & $8(30.8 \%)$ & $3(11.5 \%)$ & \multirow[t]{2}{*}{0.25} \\
\hline No & $3(11.5 \%)$ & $1(3.8 \%)$ & $3(11.5 \%)$ & \\
\hline \multicolumn{5}{|l|}{${ }^{\mathrm{a} C l i n i c a l ~ S t a g e \dagger}$} \\
\hline I & $8(23.5 \%)$ & $4(11.8 \%)$ & $3(8.8 \%)$ & \multirow[t]{2}{*}{0.93} \\
\hline II-IV & $9(26.5 \%)$ & $6(17.6 \%)$ & $4(11.8 \%)$ & \\
\hline \multicolumn{5}{|l|}{ aTreatment } \\
\hline \multicolumn{5}{|l|}{ Chemotherapy } \\
\hline Yes & $7(17.5 \%)$ & $3(7.5 \%)$ & $4(10.0 \%)$ & \multirow[t]{2}{*}{0.80} \\
\hline No & $12(30.0 \%)$ & $8(20.0 \%)$ & $6(15.0 \%)$ & \\
\hline \multicolumn{5}{|l|}{ Radiotherapy } \\
\hline Yes & $1(2.5 \%)$ & $1(2.5 \%)$ & $0(0.0 \%)$ & \multirow[t]{2}{*}{0.63} \\
\hline No & $18(45.0 \%)$ & $10(25.0 \%)$ & $10(25.0 \%)$ & \\
\hline \multicolumn{5}{|l|}{${ }^{\text {a Relapse }}$} \\
\hline Yes & $9(32.1 \%)$ & $4(14.3 \%)$ & $2(7.1 \%)$ & \multirow[t]{2}{*}{0.43} \\
\hline No & $5(17.9 \%)$ & $4(14.3 \%)$ & $4(14.3 \%)$ & \\
\hline \multicolumn{5}{|l|}{ a Mcs+PD-L1 (median cell density) } \\
\hline$\leq 1.26$ & $13(24.5 \%)$ & $10(18.9 \%)$ & $3(5.7 \%)$ & 0.40 \\
\hline$\geq 1.26$ & $11(20.8 \%)$ & $9(17.0 \%)$ & $7(13.2 \%)$ & \\
\hline \multicolumn{5}{|l|}{ Follow-up (months) 66 (12-144) } \\
\hline $\begin{array}{l}\text { aPatients censored for survival analysis at last } \\
\text { follow-up time }\end{array}$ & $8(28.6 \%)$ & $4(14.3 \%)$ & $3(10.7)$ & - \\
\hline \multicolumn{5}{|c|}{ Abbreviations: Mcs, malignant cells; PD-L1, Programmed death-ligand 1} \\
\hline \multicolumn{5}{|c|}{$\begin{array}{l}\text { aSome cases had missing follow-up information: gender (33); age (34); smoke status (47); clinical stage (39); adjuvant treatment } \\
\text { QT/RT (33); relapse (45); Mcs + PD-L1 (20); survival (47). }\end{array}$} \\
\hline
\end{tabular}

\subsection{Allele And Genotype Distributions}


All NSCLC patients who were underwent a surgical resection were successfully genotyped for the fifteen $P D-L 1$ SNPs rs76805387T $>C$, rs4742098A > G, rs47946526A > G, rs10217310G > T, rs7864231G > A, rs41280725C > T, rs573692330A > G, rs1011769981G > A, rs41280723T > C, rs138135676T > C, rs4143815G > C, rs2297136G > A, rs148242519G >A, rs41303227C > T and rs7041009G > A. The Supplementary Table 1 shows the SNP identification numbers, allele and genotype frequencies and $P$-value for HWE. Of the fifteen polymorphisms studied, eleven were monomorphic. Similar findings could also be concluded in their allele frequencies. The allele frequency of our cohort was compared to different populations of the 1000 Genomes Project (Supplementary Table 2). The monomorphic SNPs were excluded from further analysis. For the polymorphic SNPs, all were found to be in equilibrium $(P>0.05)$ for HWE.

\subsection{Correlation between PD-L1 gene polymorphisms and clinicopathological characteristics in NSCLC}

Stratified analyses of the associations between clinical characteristics and four $P D-L 1$ polymorphisms presented different genotypic distributions rs4742098A > G, rs4143815G > C, rs2297136G > A and rs7041009G > A were performed. Table 2 shows the SNP genotype frequency and the associated clinicopathological characteristics. Three of the four $P D-\angle 1$ gene polymorphisms rs $4742098 A>G$, rs4143815G >C, and rs7041009G > A were significantly associated with relapse $(P=0.01 ; P=0.05 ; P=0.02$, respectively). According to the recurrence of the disease, for the rs4742098, carriers of the $\mathrm{G}$ allele (individuals with the $\mathrm{AG}$ or $\mathrm{GG}$ genotype) were less likely to relapse $(P=$ 0.01) compared to the homozygous genotype AA. As with rs4143815, individuals with the alternative $C$ allele (genotypes CG or CC) were also less likely to relapse $(P=0.05)$. As for the rs7041009, carriers of the alternative allele A (genotypes AG or GG) more likely to exhibit relapse. The genotype GG (reference) of rs7041009 also showed a significant correlation with age, among younger patients, 16 (41.0\%) and status, among patients that are alive, 11 (39.3\%) compared to carriers of the A allele $(P=0.02$ and $P<0.01$, respectively). In these patients a marginal significance was found for smokers $(P=0.09)$ and adjuvant chemotherapy $(P=0.07)$. No was observed significant association between rs2297136 genotypes and clinicopathological variants. 
Table 2

Clinicopathologic characteristics stratified according PD-L1 polymorphisms rs 4742098, rs4143815, rs 2297136 and rs 7041009 of 70 patients with NSCLC.

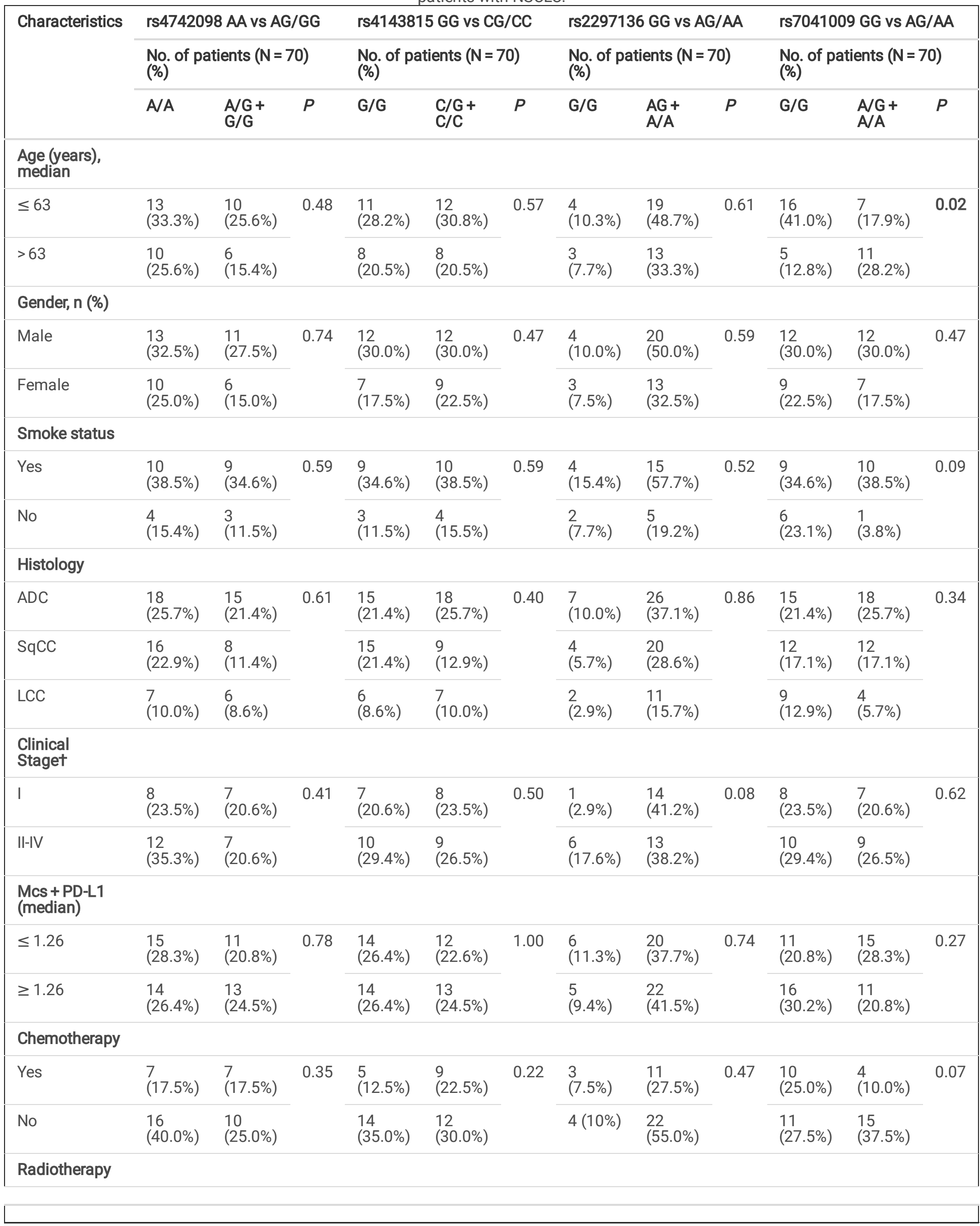

Page $8 / 20$ 


\begin{tabular}{|c|c|c|c|c|c|c|c|c|c|c|c|c|}
\hline \multirow[t]{3}{*}{ Characteristics } & \multirow{2}{*}{\multicolumn{3}{|c|}{$\begin{array}{l}\text { rs4742098 AA vs AG/GG } \\
\begin{array}{l}\text { No. of patients }(\mathrm{N}=70) \\
(\%)\end{array}\end{array}$}} & \multirow{2}{*}{\multicolumn{3}{|c|}{$\begin{array}{l}\text { rs4143815 GG vs CG/CC } \\
\begin{array}{l}\text { No. of patients }(\mathrm{N}=70) \\
(\%)\end{array}\end{array}$}} & \multirow{2}{*}{\multicolumn{3}{|c|}{$\begin{array}{l}\text { rs2297136 GG vs AG/AA } \\
\begin{array}{l}\text { No. of patients }(\mathrm{N}=70) \\
(\%)\end{array}\end{array}$}} & \multirow{2}{*}{\multicolumn{3}{|c|}{$\begin{array}{l}\text { rs7041009 GG vs AG/AA } \\
\begin{array}{l}\text { No. of patients }(\mathrm{N}=70) \\
(\%)\end{array}\end{array}$}} \\
\hline & & & & & & & & & & & & \\
\hline & AVA & $\begin{array}{l}\text { AVG + } \\
\text { G/G }\end{array}$ & $P$ & G/G & $\begin{array}{l}\mathrm{C} / \mathrm{G}+ \\
\mathrm{C} / \mathrm{C}\end{array}$ & $P$ & G/G & $\begin{array}{l}A G+ \\
\text { AVA }\end{array}$ & $P$ & G/G & $\begin{array}{l}\text { AVG + } \\
\text { AVA }\end{array}$ & $P$ \\
\hline Yes & $\begin{array}{l}1 \\
(2.5 \%)\end{array}$ & $\begin{array}{l}1 \\
(2.5 \%)\end{array}$ & \multirow[t]{2}{*}{0.67} & $\begin{array}{l}1 \\
(2.5 \%)\end{array}$ & $\begin{array}{l}1 \\
(2.5 \%)\end{array}$ & \multirow[t]{2}{*}{0.73} & $\begin{array}{l}1 \\
(2.5 \%)\end{array}$ & $\begin{array}{l}1 \\
(2.5 \%)\end{array}$ & \multirow[t]{2}{*}{0.32} & $\begin{array}{l}0 \\
(0.0 \%)\end{array}$ & $\begin{array}{l}2 \\
(5.0 \%)\end{array}$ & \multirow[t]{2}{*}{0.21} \\
\hline No & $\begin{array}{l}22 \\
(55.0 \%)\end{array}$ & $\begin{array}{l}16 \\
(40.0 \%)\end{array}$ & & $\begin{array}{l}18 \\
(45.0 \%)\end{array}$ & $\begin{array}{l}20 \\
(50.0 \%)\end{array}$ & & $\begin{array}{l}6 \\
(15.0 \%)\end{array}$ & $\begin{array}{l}32 \\
(80.0 \%)\end{array}$ & & $\begin{array}{l}21 \\
(52.5 \%)\end{array}$ & $\begin{array}{l}17 \\
(42.5 \%)\end{array}$ & \\
\hline \multicolumn{13}{|l|}{ Relapse } \\
\hline Yes & $\begin{array}{l}11 \\
(39.3 \%)\end{array}$ & $\begin{array}{l}4 \\
(14.3 \%)\end{array}$ & \multirow[t]{2}{*}{0.01} & $\begin{array}{l}9 \\
(32.1 \%)\end{array}$ & $\begin{array}{l}6 \\
(21.4 \%)\end{array}$ & \multirow[t]{2}{*}{0.05} & $\begin{array}{l}5 \\
(17.9 \%)\end{array}$ & $\begin{array}{l}10 \\
(35.7 \%)\end{array}$ & \multirow[t]{2}{*}{0.25} & $\begin{array}{l}5 \\
(17.9 \%)\end{array}$ & $\begin{array}{l}10 \\
(35.7 \%)\end{array}$ & \multirow[t]{2}{*}{0.02} \\
\hline No & $\begin{array}{l}3 \\
(10.7 \%)\end{array}$ & $\begin{array}{l}10 \\
(35.7 \%)\end{array}$ & & $\begin{array}{l}3 \\
(10.7 \%)\end{array}$ & $\begin{array}{l}10 \\
(35.7 \%)\end{array}$ & & $\begin{array}{l}2 \\
(7.1 \%)\end{array}$ & $\begin{array}{l}11 \\
(39.3 \%)\end{array}$ & & $\begin{array}{l}10 \\
(35.7 \%)\end{array}$ & $\begin{array}{l}3 \\
(10.7 \%)\end{array}$ & \\
\hline \multicolumn{13}{|l|}{ Status } \\
\hline Live & $\begin{array}{l}5 \\
(17.9 \%)\end{array}$ & $\begin{array}{l}8 \\
(28.6 \%)\end{array}$ & \multirow[t]{2}{*}{0.34} & $\begin{array}{l}5 \\
(17.9 \%)\end{array}$ & $\begin{array}{l}8 \\
(28.6 \%)\end{array}$ & \multirow[t]{2}{*}{0.62} & $\begin{array}{l}3 \\
(10.7 \%)\end{array}$ & $\begin{array}{l}10 \\
(35.7 \%)\end{array}$ & \multirow[t]{2}{*}{0.60} & $\begin{array}{l}11 \\
(39.3 \%)\end{array}$ & $\begin{array}{l}2 \\
(7.1 \%)\end{array}$ & \multirow[t]{2}{*}{0.00} \\
\hline Dead & $\begin{array}{l}8 \\
(28.6 \%)\end{array}$ & $\begin{array}{l}7 \\
(25.0 \%)\end{array}$ & & $\begin{array}{l}6 \\
(21.4 \%)\end{array}$ & $\begin{array}{l}9 \\
(32.1 \%)\end{array}$ & & $\begin{array}{l}3 \\
(10.7 \%)\end{array}$ & $\begin{array}{l}12 \\
(42.9 \%)\end{array}$ & & $\begin{array}{l}3 \\
(10.7 \%)\end{array}$ & $\begin{array}{l}12 \\
(42.9 \%)\end{array}$ & \\
\hline
\end{tabular}

\subsection{Correlation between PD-L1 protein expression and PD-L1 gene polymorphisms}

The correlation between PD-L1 protein expression and PD-L1 gene polymorphisms are shown in Table 2. No statistically significant association between PD-L1 protein expression in malignant cells and $P D-L 1$ gene polymorphisms was observed.

In our cohort, the four PD-L1 gene polymorphisms, apparently, are not interfering in the expression of PD-L1 in malignant cells of NSCLC. However, when we correlate the PD-L1 protein expression among the ADC, SqCC and LCC histological subtypes, we observed that the expression was below the median for malignant cell of all histological subtypes.

\subsection{Survival Analysis}

In the first statistical test, were examined the individual effect of patient characteristics, such as age, sex, tobacco history, histology, clinical stage, treatment and polymorphisms to estimate statistical differences using Kaplan-Meier survival curves (Table 3 ). The results of this analysis showed that the prognosis of patients with NSCLC is strongly dependent on the alternative allele $G$ (genotype AG or GG) of rs 4742098, alternative allele C (genotype CG or CC) of rs4143815 and individuals with GG genotype of rs7041009 $(P=0.02 ; P=0.05$ and $P$ $<0.01$, respectively). Age presented a significant marginal value $(P=0.07)$, and patients younger than 63 years seemed to have an increased overall cancer survival than patients older than 63 years. Radiotherapy also presented marginally significant value $(P=0.09)$, and patients treated with radiotherapy presented lower survival than patients without treatment. 
Table 3

Survival analysis with stratification of the variables in optimal upper and lower binary cut-off limits by the Kaplan-Meier method stratified for relapse occurrence and the differences by means of the log-rank test.

\begin{tabular}{|c|c|c|c|c|}
\hline \multirow[t]{2}{*}{ Variables } & \multicolumn{2}{|c|}{ Overall Survival (months) } & \multirow{2}{*}{$\begin{array}{l}\text { Chi-Square } \\
\text { (Log Rank) }\end{array}$} & \multirow[t]{2}{*}{$P$-value } \\
\hline & Mean & Standard Error & & \\
\hline \multicolumn{5}{|l|}{ Age (yrs) } \\
\hline$\leq 63$ & 106.31 & 13.82 & 3.19 & 0.07 \\
\hline$>63$ & 65.48 & 16.32 & & \\
\hline \multicolumn{5}{|l|}{ Gender } \\
\hline Male & 71.93 & 12.83 & \multirow[t]{2}{*}{0.12} & \multirow[t]{2}{*}{0.72} \\
\hline Female & 93.33 & 16.63 & & \\
\hline \multicolumn{5}{|l|}{ Smoke status } \\
\hline Yes & 89.50 & 18.09 & \multirow[t]{2}{*}{0.44} & \multirow[t]{2}{*}{0.50} \\
\hline No & 91.50 & 12.51 & & \\
\hline \multicolumn{5}{|l|}{ Histology } \\
\hline ADC & 77.14 & 14.58 & \multirow[t]{3}{*}{0.89} & \multirow[t]{3}{*}{0.64} \\
\hline $\mathrm{SqCC}$ & 75.00 & 17.68 & & \\
\hline LCC & 107.20 & 21.33 & & \\
\hline \multicolumn{5}{|l|}{ Clinical Stage $†$} \\
\hline I & 102.85 & 18.11 & \multirow[t]{2}{*}{1.00} & \multirow[t]{2}{*}{0.31} \\
\hline II-IV & 79.03 & 14.58 & & \\
\hline \multicolumn{5}{|l|}{ Treatment } \\
\hline \multicolumn{5}{|l|}{ Chemotherapy } \\
\hline Yes & 107.55 & 14.75 & \multirow[t]{2}{*}{1.96} & \multirow[t]{2}{*}{0.16} \\
\hline No & 71.34 & 14.78 & & \\
\hline \multicolumn{5}{|l|}{ Radiotherapy } \\
\hline Yes & 12.00 & 0.00 & \multirow[t]{2}{*}{2.85} & \multirow[t]{2}{*}{0.09} \\
\hline No & 89.06 & 11.32 & & \\
\hline \multicolumn{5}{|l|}{ Status } \\
\hline Live & 128.72 & 9.89 & \multirow[t]{2}{*}{16.13} & \multirow[t]{2}{*}{0.00} \\
\hline Dead & 44.05 & 9.54 & & \\
\hline \multicolumn{5}{|l|}{ Mcs + PD-L1 (median cell density) } \\
\hline$\leq 1.26$ & 76.00 & 18.90 & \multirow[t]{2}{*}{0.00} & \multirow[t]{2}{*}{0.92} \\
\hline$\geq 1.26$ & 89.77 & 18.23 & & \\
\hline PD-L1 polymorphisms & & & & \\
\hline rs4742098 (AA vs AG/GG genotype) & & & & \\
\hline
\end{tabular}

Abbreviations: ADC, Adenocarcinoma; SqCC, Squamous cell carcinoma; LCC, Large cell carcinoma. Mcs, malignant cells; PD-L1, Programmed death-ligand 1

† 7th International Association for the Study of Lung Cancer [17]. 


\begin{tabular}{|c|c|c|c|c|}
\hline Variables & \multicolumn{2}{|c|}{ Overall Survival (months) } & \multicolumn{2}{|l|}{ (Log Rank) } \\
\hline AA & 56.00 & 10.21 & \multirow[t]{2}{*}{5.25} & \multirow[t]{2}{*}{0.02} \\
\hline AG/GG & 115.71 & 14.49 & & \\
\hline \multicolumn{5}{|c|}{ rs4143815 (GG vs CG/CC genotype) } \\
\hline GG & 53.45 & 11.58 & \multirow[t]{2}{*}{3.76} & \multirow[t]{2}{*}{0.05} \\
\hline CG/CC & 107.22 & 13.53 & & \\
\hline \multicolumn{5}{|c|}{ rs2297136 (GG vs AG/AA genotype) } \\
\hline GG & 64.00 & 23.60 & \multirow[t]{2}{*}{0.99} & \multirow[t]{2}{*}{0.31} \\
\hline AG/AA & 93.35 & 12.25 & & \\
\hline \multicolumn{5}{|c|}{ rs7041009 (GG vs AG/AA genotype) } \\
\hline GG & 110.98 & 14.00 & \multirow[t]{2}{*}{6.76} & \multirow[t]{2}{*}{0.00} \\
\hline AG/AA & 56.18 & 13.11 & & \\
\hline \multicolumn{5}{|c|}{$\begin{array}{l}\text { Abbreviations: ADC, Adenocarcinoma; SqCC, Squamous cell carcinoma; LCC, Large cell carcinoma. Mcs, malignant cells; PD-L1, } \\
\text { Programmed death-ligand } 1\end{array}$} \\
\hline
\end{tabular}

As observed in Fig. 1, carriers of the G allele (individuals with the AG or GG genotype) of the rs 4742098 genotype were more associated with higher survival overall rate compared to AA genotype. The median OS time was 115.71 months (95\% confidence interval [CI]: 87.29 months to 144.13 months) for AG, and GG genotypes was 56.00 months (Cl: 35.97 months to 76.02 months) $(P=0.02)$. The OS for patients presenting genotypes $C G$ and CC of rs 4143815 were also higher than patients presenting genotype GG. The median OS time was 107.22 months (Cl: 80.68 months to 133.75 months) for CG and CC genotypes and 53.45 months (Cl: 30.75 months to 76.15 months) $(P=$ 0.05; Fig. 2). In contrast, OS for carriers of the A allele (individuals with the AG or AA genotype) of rs7041009 was lower than patients presenting genotype GG. The median OS time was 56.18 months (Cl: 30.47 months to 81.88 months) carriers of the A allele and 110.98 months (Cl: 83.53 months to 138.43 months) for $\mathrm{GG}$ genotype $(P<0.01$; Fig. 3).

Using the Cox Regression model was examined the multivariate analysis of tumor recurrence risk (Hazard Ratio [HR]) based on significant and marginal significant factors at univariate analysis. Initially, the model was constructed with patient age, radiotherapy and tumor relapse (Table 4). In this situation, were maintained as independent risk factors the radiotherapy and tumor recurrence; age did not show a significant statistical value. Thus, $P D-L 1$ polymorphisms were introduced into the model, controlled for age, radiotherapy and tumor relapse. This new situation showed that among the four $P D-L 1$ polymorphisms genes, only genotype GG of $P D-L 1$ rs 7041009 was significant in predicting cancer recurrence in patients without treatment with radiotherapy $(\mathrm{HR}=7.59, \mathrm{Cl}=1.06-54.03$, and $\mathrm{HR}=9.24, \mathrm{Cl}=$ 1.13-75.16; Table 4). Thus, patients with NSCLC presenting PD-L1 rs7041009 polymorphism who did not receive treatment with radiotherapy were associated with the risk of cancer recurrence. 
Table 4

Variables associated with overall survival (OS) of 70 patients diagnosed with NSCLC. Univariate and multivariate analysis employed a Cox proportional hazards model

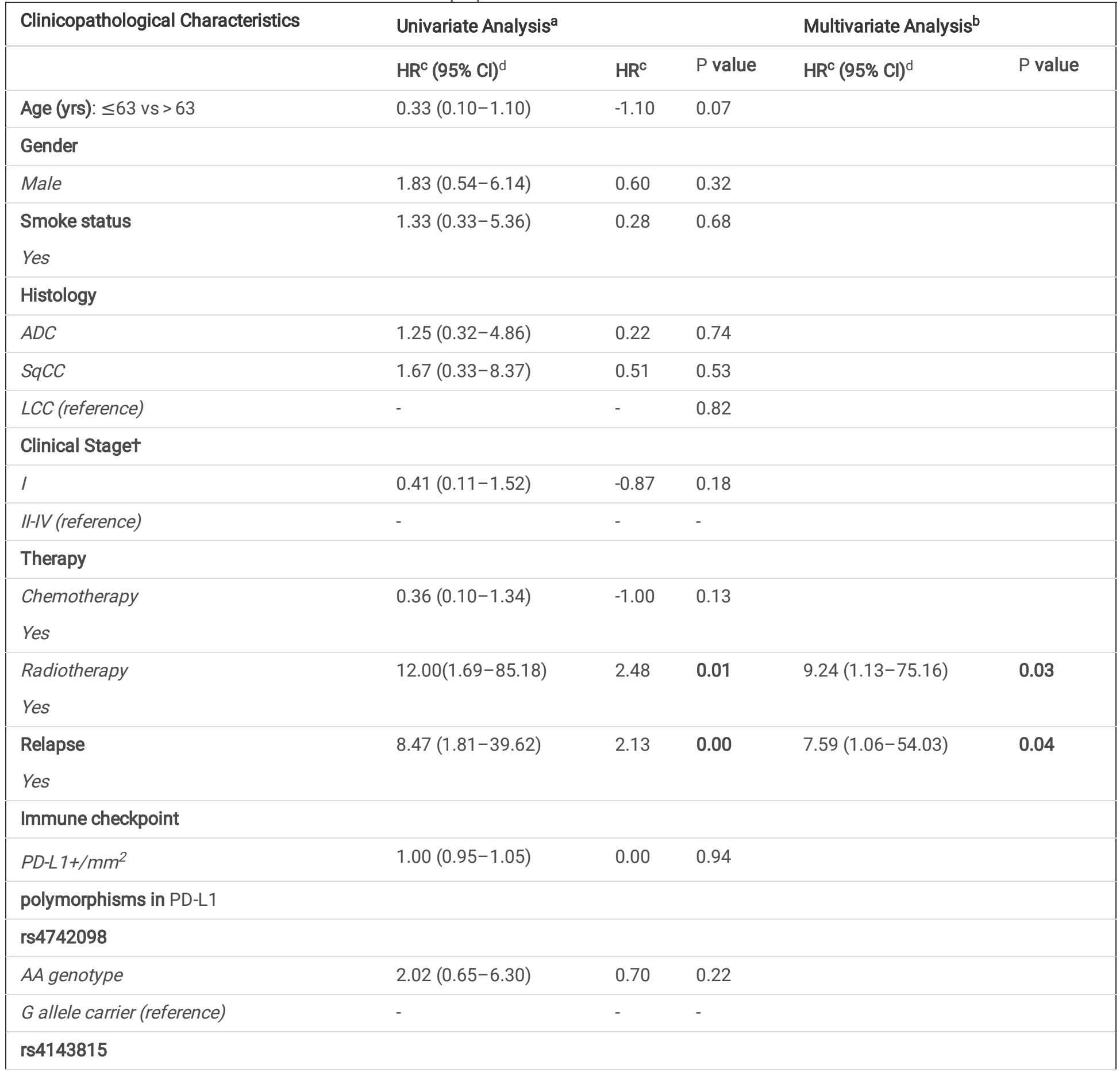

Abbreviations: ADC, Adenocarcinoma; SqCC, Squamous cell carcinoma; LCC, Large cell carcinoma; $\mathrm{HR}=\mathrm{hazard}$ ratio ( $\beta$ coefficient); Cl = confidence interval; PD-L1, Programmed death-ligand 1.

† 7th International Association for the Study of Lung Cancer [17].

\section{Additional files}

Additional file 1:

Supplementary Table 1. Allele frequency of genotyped single nucleotide polymorphisms (SNPs) present in the study and in different populations of the 1000 Genomes project (DOCX 22,2 KB)

Additional file 2:

Supplementary Table 2. Genotype, allele distributions and HWE test for SNPs in 70 patients diagnosed with NSCLC (DOCX 21,8 KB) 


\begin{tabular}{|c|c|c|c|c|c|}
\hline \multirow{2}{*}{$\begin{array}{l}\text { Clinicopathological Characteristics } \\
\text { GG genotype }\end{array}$} & \multicolumn{3}{|l|}{ Univariate Analysis ${ }^{a}$} & \multicolumn{2}{|c|}{ Multivariate Analysis $^{b}$} \\
\hline & $1.58(0.52-4.81)$ & 0.46 & 0.41 & & \\
\hline C allele carrier (reference) & - & - & - & & \\
\hline \multicolumn{6}{|l|}{ rs2297136 } \\
\hline GG genotype & $1.24(0.34-4.55)$ & 0.22 & 0.73 & & \\
\hline A allele carrier (reference) & - & - & - & & \\
\hline \multicolumn{6}{|l|}{ rs7041009 } \\
\hline GG genotype & $0.20(0.05-0.76)$ & -1.56 & 0.01 & $0.78(0.14-4.40)$ & 0.78 \\
\hline A allele carrier (reference) & - & - & - & & \\
\hline
\end{tabular}

Abbreviations: ADC, Adenocarcinoma; SqCC, Squamous cell carcinoma; $L C C$, Large cell carcinoma; $\mathrm{HR}$ = hazard ratio ( $\beta$ coefficient); $\mathrm{Cl}$ = confidence interval; PD-L1, Programmed death-ligand 1.

† 7th International Association for the Study of Lung Cancer [17].

\section{Additional files}

Additional file 1:

Supplementary Table 1. Allele frequency of genotyped single nucleotide polymorphisms (SNPs) present in the study and in different populations of the 1000 Genomes project (DOCX 22,2 KB)

Additional file 2:

Supplementary Table 2. Genotype, allele distributions and HWE test for SNPs in 70 patients diagnosed with NSCLC (DOCX 21,8 KB)

\section{Discussion}

The present work showed that the association between clinical data and single-nucleotide polymorphisms (SNPs) in the $P D-L 1$ gene influences the risk of disease recurrence and adjuvant treatment. Seventy diagnosed and surgically removed NSCLC, were used for PD-L1 multiplex immunofluorescence (mIF) assays and NGS sequencing. Under the conditions of the present investigation, we found a variety of associated effects between polymorphism in the $P D-L 1$ gene profile and behavior of NSCLC. They included: 1) PD-L1 protein expression higher in ADC than in SqCC and LCC; 2) three of the four $P D-L 1$ gene polymorphisms rs4742098, rs4143815 and rs7041009 significantly associated with tumor recurrence; 3) different frequencies of genotypes rs4742098 A/A, rs4143815 G/G, and rs7041009 A/G or A/A genotypes; 4) G allele of rs7041009 significantly correlated with younger patients and status; 5) rs7041009 A>G genotype inversely associated with E1L3N PD-L1 labeling in NSCLCs; 6) prognosis of patients with NSCLC strongly dependent on the genotype; and 7) genotype G/G of $P D-L 1$ rs7041009 independently associated with risk of cancer recurrence and patients without postoperative radiotherapy.

To better understand the role of SNPs in the $P D-L 1$ gene on the risk of disease recurrence and adjuvant treatment, our study was carried out in a cohort of patients including metastatic and non-metastatic NSCLC. We analyzed the tumor profile in 70 NSCLC patients for the occurrence of $P D-L 1$ gene polymorphisms in fresh-frozen lung cancer tissue. Our investigation included ADC, SqCC, and LCC, and to our knowledge is the first study comparing SNPs in the PD-L1 gene among the three major histological types of NSCLC, and its impact on disease progression.

In this study, we detected that positive malignant cells expressing PD-L1 (MCs PD-L1) using Cell Signaling E1L3N clone, mIF and image analysis were positively correlated with ADC above the median in $11(20.8 \%)$ when compared to others histological subtypes. In fact, Shimoji et al [22] showed that PD-L1 expression using the Cell Signaling E1L3N clone was significantly correlated with a solid, vimentin expression, increased Ki-67 labeling index and poor prognosis in ADC but not in SqCC. Other studies have reported that IHC staining for PD-L1 was detected at significantly higher frequencies in SqCC than in ADC of the lung [22, 23]. Cha et al. [24] found that PD-L1 expression of the Ventana Laboratory SP142 clone was significantly associated with an ADC solid subtype histology, p53 aberrant expression, and poor prognosis.

In our cohort, we also evaluated the relationship between genotype distributions of PD-L1 SNPs and NSCLC patients who underwent a surgical resection. Actually, gene polymorphism is one of the most common gene variations, and functional polymorphisms may affect

Page $13 / 20$ 
mRNA and protein expression levels $[4,16,25,26]$. We found that $P D-L 1$ polymorphisms presented different genotypic distributions rs4742098A > G, rs4143815G >C, rs2297136G >A and rs7041009G > A. Interestingly, three of the four $P D-L 1$ gene polymorphisms rs4742098A $>$ G, rs4143815G $>C$ and rs7041009G $>$ A were significantly associated with disease recurrence. According to the recurrence of the disease, for the rs4742098, carriers of the $G$ allele (individuals with the AG or GG genotype) were less likely to relapse compared to the homozygous genotype AA. Similar findings were reported by Du and colleagues [25] for the rs4742098 SNP, which AG genotype differed from the AA genotype on evaluation of the risk of NSCLC recurrence.

Concerning rs4143815, we found that patients with the alternative $C$ allele (genotypes CG or CC) were also less likely to disease relapse in agreement with Nomizo and colleagues report [26]. Regarding rs7041009, carriers of the alternative allele A (genotypes AG or GG) were more likely to exhibit relapse. The genotype GG (reference) of rs7041009 also showed a significant correlation with age, among younger patients, 16 (41.0\%) and status, among patients that are alive, 11 (39.3\%) compared to carriers of the A allele. The SNP rs7041009 was in the region of the transcription factor-binding site of $P D-L 1$. We expected that the polymorphism of rs 7041009 might change the binding power between transcription factors and $P D-L 1$, which leads to the up-regulation or downregulation of $P D-L 1$ transcription and PD-L1 protein expression. Unfortunately, we did not find a difference in the positive rate of PD-L1 protein expression in patients with different genotypes of $P D-L 1$. Apparently, this finding suggests that genotypes of $P D-L 1$ do not interfere in the expression of PD-L1 in the malignant cells of NSCLC. However, when we correlate the PD-L1 protein expression among the ADC, SqCC and LCC histological subtypes, we observed that the expression was below the median for malignant cell of all histological subtypes eventually related to downregulation of $P D-L 1$ transcription. In addition, the specimens from our patients were analyzed with mIF staining of the PD-L1 protein and quantified by image analysis, while other authors used IHC staining and $\mathrm{H}$-score, which may have limited the statistical power.

Surgery is the standard treatment for patients with an early clinical stage and selected patients with stage IIIA disease with the possibility of complete tumor resection, but the overall 5 -year survival remains below $50 \%$. The addition of adjuvant cisplatin-based chemotherapy to surgery improved 5 -year survival rates by $5-10 \%$. Over the last decade, significant progress has been made in systemic therapies to improve the length of good-quality survival in patients with metastatic or recurrent NSCLC [27, 28]. Following these systemic NSCLC treatments, patients with metastatic disease can be treated with the addition of local radiotherapy to improve treatment efficacy and patient survival compared to chemotherapy alone. More recently, adjuvant radiotherapy induced PD-L1 protein expression in initially PD-L1 negative tumor enabling, thereby subsequent effective immunotherapy [29]. However, not all NSCLC patients are good responders to immunotherapy, because the immune profiling heterogeneity of expression probably depends on alterations in other factors, such as $P D-L 1$ gene polymorphism.

In our cohort, Kaplan-Meier survival curves and log-rank tests showed a significant association between patients with NSCLC carrier of the alternative allele $\mathrm{G}$ (genotype AG or GG) of rs4742098, alternative allele C (genotype CG or CC) of rs 4143815 and patients with GG genotype of rs7041009 with shorter disease-free survival. Similar findings were reported by Lee and colleagues [16] who found $P D-L 1$ rs $4143815 \mathrm{C}>\mathrm{G}$ significantly associated with worse survival outcomes in multivariate analyses. Moreover, patients with the CC and CG genotypes of $P D-L 1$ rs 4143815 showed slightly better responses to nivolumab [26]. In agreement with Lee and colleagues [16] we also found that patients with postoperative chemotherapy and radiotherapy presented a tendency of better survival compared to patients not treated.

Contrary to our result, another study found that rs $822336 \mathrm{G}$ to $\mathrm{C}$ substitutions was significantly associated with worse survival of earlystage non-small-cell lung cancer [16]. This indicated that the association between $P D-L 1$ gene polymorphisms and survival in different tumors might not be consistent. Multivariate analysis of the survival risk (Hazard Ratio) based on significant and marginal significant factors at univariate analysis was examined by the Cox regression model. Initially, the model was constructed with patient age, radiotherapy and tumor relapse. In this situation, radiotherapy, and tumor recurrence were maintained as independent risk factors; age did not show a significant statistical value. Thus, $P D-L 1$ polymorphisms were introduced into the model, controlled for age, radiotherapy and tumor relapse. This new situation showed that among the four $P D-L 1$ polymorphisms genes, only genotype GG of $P D-L 1$ rs 7041009 was significant in predicting cancer recurrence in patients without adjuvant treatment with radiotherapy. Thus, patients with NSCLC presenting $P D-L 1$ rs7041009 polymorphism who did not receive treatment with radiotherapy were associated with the risk of cancer recurrence.

Our analysis had several potential limitations. The first and major limitation consisted that it was not possible to investigate the risk of lung cancer related to $P D-L 1$ polymorphisms because we did not perform a case-control approach. Second, the modest sample size of 70 participants. However, the current study has strengths that should be mentioned; the analysis revealed that these SNPs had significant associations with clinicopathological features, including tumor relapse and overall survival of patients. Further studies are needed to provide additional insight that which gives strength to our findings and help to understand the underlying mechanisms that cover SNPs of $P D-L 1$ in determining the clinical outcome of relapse in patients with NSCLC.

Page $14 / 20$ 


\section{Conclusion}

The present study showed the PD-L1 rs7041009 GG polymorphisms might be useful for the prediction of clinical outcome of radiotherapy in NSCLC. Thus, those findings may provide insights for targeted lung cancer screening and drug development.

However, further studies are needed to confirm our findings and to understand the role of PD-L1 in the radiotherapy outcome of NSCLC patients.

\section{Abbreviations}

$A D$

Allele depth

ADC

Lung adenocarcinoma

$\mathrm{Cl}$

95\% confidence interval

gDNA

Genomic DNA

HC-FMUSP

Hospital das Clinicas of the State University of São Paulo Medical School

HR

Hazard Ratio

ICESP

Cancer Institute of São Paulo

IF

Immunofluorescence

INCOR

Heart Institute of the University of São Paulo

LCC

Large cell carcinoma

MCs

Malignant cells

$\mathrm{mIF}$

Multiplex immunofluorescence

NSCLC

Non-small cell lung cancer

OS

Overall survival

PD

Position depth

PD-1

Programmed death-1

PD-L1

Programmed death-ligand 1

SNPS

Single-nucleotide polymorphisms

SqCC

Squamous cell carcinoma

\section{Declarations}

\section{Acknowledgements}

We appreciate all subjects who participated in this study and the lllumina members for assistance with the initial runs. 


\section{Funding}

The research reported in this publication was supported in part by the São Paulo Research Foundation (FAPESP) [2018/20403-6] and the National Council for Scientific and Technological Development (CNPq) [483005/2012-6].

\section{Availability of data and materials}

All data generated or analysed during this study are included in this published article [and its supplementary information files].

\section{Authors' contributions}

JMR: Conceptualization, Formal analysis, Investigation, Methodology, Resources, Writing- original draft.

TGP: Conceptualization, Formal analysis, Investigation, Methodology, Writing- original draft.

ATF: Formal analysis, Resources.

ERPC: Resources.

VKS: Resources

CMB: Investigation, Writing- review \& edit.

CAR: Validation.

ECC: Formal analysis.

CF: Formal analysis, Investigation.

TYT: Investigation.

MAN: Validation, Writing- review \& edit.

VLC: Conceptualization, Formal analysis, Funding acquisition, Project administration, Writing- review \& edit.

Ethics approval and consent to participate

Ethics Committee in Human Research at University of São Paulo Medical School approved the study (Process number: 2.673.320/2018). Consent for patients' participation was waived because this was a retrospective study using archived material that did not increase patient risk.

\section{Consent for publication}

Not applicable.

\section{Competing interests}

The authors declare that they have no competing interests.

\section{References}

1. Hirsch FR, Scagliotti GV, Mulshine JL, Kwon R, Curran WJ, Wu Y-L, et al. Lung cancer: current therapies and new targeted treatments. The Lancet. 2017;389(10066):299-311. doi:10.1016/S0140-6736(16)30958-8.

2. Berghmans T, Durieux V, Hendriks LEL, Dingemans AM. Immunotherapy: From Advanced NSCLC to Early Stages, an Evolving Concept. Front Med (Lausanne). 2020;7:90. doi:10.3389/fmed.2020.00090.

3. Bylicki O, Paleiron N, Rousseau-Bussac G, Chouaïd C. New PDL1 inhibitors for non-small cell lung cancer: focus on pembrolizumab. Onco Targets Ther. 2018;11:4051-64. doi:10.2147/0TT.S154606.

4. Yeo MK, Choi SY, Seong IO, Suh KS, Kim JM, Kim KH. Association of PD-L1 expression and PD-L1 gene polymorphism with poor prognosis in lung adenocarcinoma and squamous cell carcinoma. Hum Pathol. 2017;68:103-11.

doi:10.1016/j.humpath.2017.08.016. 
5. Francisco LM, Salinas VH, Brown KE, Vanguri VK, Freeman GJ, Kuchroo VK, et al. PD-L1 regulates the development, maintenance, and function of induced regulatory T cells. J Exp Med. 2009;206(13):3015-29. doi:10.1084/jem.20090847.

6. Lantuejoul S, Damotte D, Hofman V, Adam J. Programmed death ligand 1 immunohistochemistry in non-small cell lung carcinoma. J Thorac Dis. 2019;11(Suppl 1):89-101. doi:10.21037/jtd.2018.12.103.

7. Yu H, Boyle TA, Zhou C, Rimm DL, Hirsch FR. PD-L1 Expression in Lung Cancer. J Thorac Oncol. 2016;11(7):964-75. doi:10.1016/j.jtho.2016.04.014.

8. Aggarwal C, Abreu DR, Felip E, Carcereny E, Gottfried M, Wehler T, et al. 1060P - Prevalence of PD-L1 expression in patients with nonsmall cell lung cancer screened for enrollment in KEYNOTE-001, -010, and - 024. Ann Oncol. 2016;27:vi363. doi:10.1093/annonc/mdw378.

9. Reck M, Rodríguez-Abreu D, Robinson AG, Hui R, Csőszi T, Fülöp A, et al. Pembrolizumab versus Chemotherapy for PD-L1-Positive NonSmall-Cell Lung Cancer. N Engl J Med. 2016;375(19):1823-33. doi:10.1056/NEJMoa1606774.

10. Marwitz S, Scheufele S, Perner S, Reck M, Ammerpohl O, Goldmann T. Epigenetic modifications of the immune-checkpoint genes CTLA4 and PDCD1 in non-small cell lung cancer results in increased expression. Clin Epigenetics. 2017;9:51. doi:10.1186/s13148017-0354-2.

11. Chen L, Gibbons DL, Goswami S, Cortez MA, Ahn YH, Byers LA, et al. Metastasis is regulated via microRNA-200/ZEB1 axis control of tumour cell PD-L1 expression and intratumoral immunosuppression. Nat Commun. 2014;5:5241. doi:10.1038/ncomms6241.

12. Ma Y, Adjemian S, Mattarollo SR, Yamazaki T, Aymeric L, Yang H, et al. Anticancer chemotherapy-induced intratumoral recruitment and differentiation of antigen-presenting cells. Immunity. 2013;38(4):729-41. doi:10.1016/j.immuni.2013.03.003.

13. Mazzaschi G, Madeddu D, Falco A, Bocchialini G, Goldoni M, Sogni F, et al. Low PD-1 Expression in Cytotoxic CD8(+) Tumor-Infiltrating Lymphocytes Confers an Immune-Privileged Tissue Microenvironment in NSCLC with a Prognostic and Predictive Value. Clin Cancer Res. 2018;24(2):407-19. doi:10.1158/1078-0432.CCR-17-2156.

14. de Vooght KMK, van Wijk R, van Solinge WW. Management of Gene Promoter Mutations. in Molecular Diagnostics. 2009;55(4):698708. doi:10.1373/clinchem.2008.120931.

15. Hashemi M, Karami S, Sarabandi S, Moazeni-Roodi A, Małecki A, Ghavami S, et al. Association between PD-1 and PD-L1 Polymorphisms and the Risk of Cancer: A Meta-Analysis of Case-Control Studies. 2019; 11(8):1150. doi: 10.3390/cancers11081150.

16. Lee SY, Jung DK, Choi JE, Jin CC, Hong MJ, Do SK, et al. Functional polymorphisms in PD-L1 gene are associated with the prognosis of patients with early stage non-small cell lung cancer. Gene. 2017;599:28-35. doi:10.1016/j.gene.2016.11.007.

17. Li H, Durbin R. Fast and accurate short read alignment with Burrows-Wheeler transform. Bioinformatics. 2009;25(14):1754-60. doi:10.1093/bioinformatics/btp324.

18. McLaren W, Gil L, Hunt SE, Riat HS, Ritchie GRS, Thormann A, et al. The Ensembl Variant Effect Predictor. Genome Biology. 2016;17(1):122. doi:10.1186/s13059-016-0974-4.

19. Parra ER, Uraoka N, Jiang M, Cook P, Gibbons D, Forget M-A, et al. Validation of multiplex immunofluorescence panels using multispectral microscopy for immune-profiling of formalin-fixed and paraffin-embedded human tumor tissues. Sci Rep. 2017;7(1):13380. doi:10.1038/s41598-017-13942-8.

20. Parra ER, Jiang M, Machado-Rugolo J, Yaegashi LB, Prieto T, Farhat C, et al. Variants in Epithelial-Mesenchymal Transition and Immune Checkpoint Genes Are Associated With Immune Cell Profiles and Predict Survival in Non-Small Cell Lung Cancer. Arch Pathol Lab Med. 2020. doi:10.5858/arpa.2019-0419-0A.

21. Gorris MAJ, Halilovic A, Rabold K, van Duffelen A, Wickramasinghe IN, Verweij D, et al. Eight-Color Multiplex Immunohistochemistry for Simultaneous Detection of Multiple Immune Checkpoint Molecules within the Tumor Microenvironment. J Immunol. 2018;200(1):347-54. doi:10.4049/jimmunol.1701262.

22. Shimoji M, Shimizu S, Sato K, Suda K, Kobayashi Y, Tomizawa K, et al. Clinical and pathologic features of lung cancer expressing programmed cell death ligand 1 (PD-L1). Lung Cancer. 2016;98:69-75. doi:10.1016/j.lungcan.2016.04.021.

23. Takada K, Toyokawa G, Okamoto T, Shimokawa M, Kozuma Y, Matsubara T, et al. A Comprehensive Analysis of Programmed Cell Death Ligand-1 Expression With the Clone SP142 Antibody in Non-Small-Cell Lung Cancer Patients. Clin Lung Cancer. 2017;18(5):572-82. doi:10.1016/j.cllc.2017.02.004.

24. Cha YJ, Kim HR, Lee CY, Cho BC, Shim HS. Clinicopathological and prognostic significance of programmed cell death ligand-1 expression in lung adenocarcinoma and its relationship with p53 status. Lung Cancer. 2016;97:73-80. doi:10.1016/j.lungcan.2016.05.001. 
25. Du W, Zhu J, Chen Y, Zeng Y, Shen D, Zhang N, et al. Variant SNPs at the microRNA complementary site in the B7-H1 3'-untranslated region increase the risk of non-small cell lung cancer. Mol Med Rep. 2017;16(3):2682-90. doi:10.3892/mmr.2017.6902.

26. Nomizo T, Ozasa H, Tsuji T, Funazo T, Yasuda Y, Yoshida H, et al. Clinical Impact of Single Nucleotide Polymorphism in PD-L1 on Response to Nivolumab for Advanced Non-Small-Cell Lung Cancer Patients. Sci Rep. 2017;7(1):45124. doi:10.1038/srep45124.

27. Planchard D, Popat S, Kerr K, Novello S, Smit EF, Faivre-Finn C, et al. Metastatic non-small cell lung cancer: ESMO Clinical Practice Guidelines for diagnosis, treatment and follow-up. Ann Oncol. 2018;29(suppl 4):iv192-237. doi:10.1093/annonc/mdy275.

28. Gandhi L, Rodríguez-Abreu D, Gadgeel S, Esteban E, Felip E, De Angelis F, et al. Pembrolizumab plus Chemotherapy in Metastatic NonSmall-Cell Lung Cancer. N Engl J Med. 2018;378(22):2078-92. doi:10.1056/NEJMoa1801005.

29. Narits J, Tamm H, Jaal J. PD-L1 induction in tumor tissue after hypofractionated thoracic radiotherapy for non-small cell lung cancer. Clin Transl Radiat Oncol. 2020;22:83-7. doi:10.1016/j.ctro.2020.04.003.

\section{Figures}

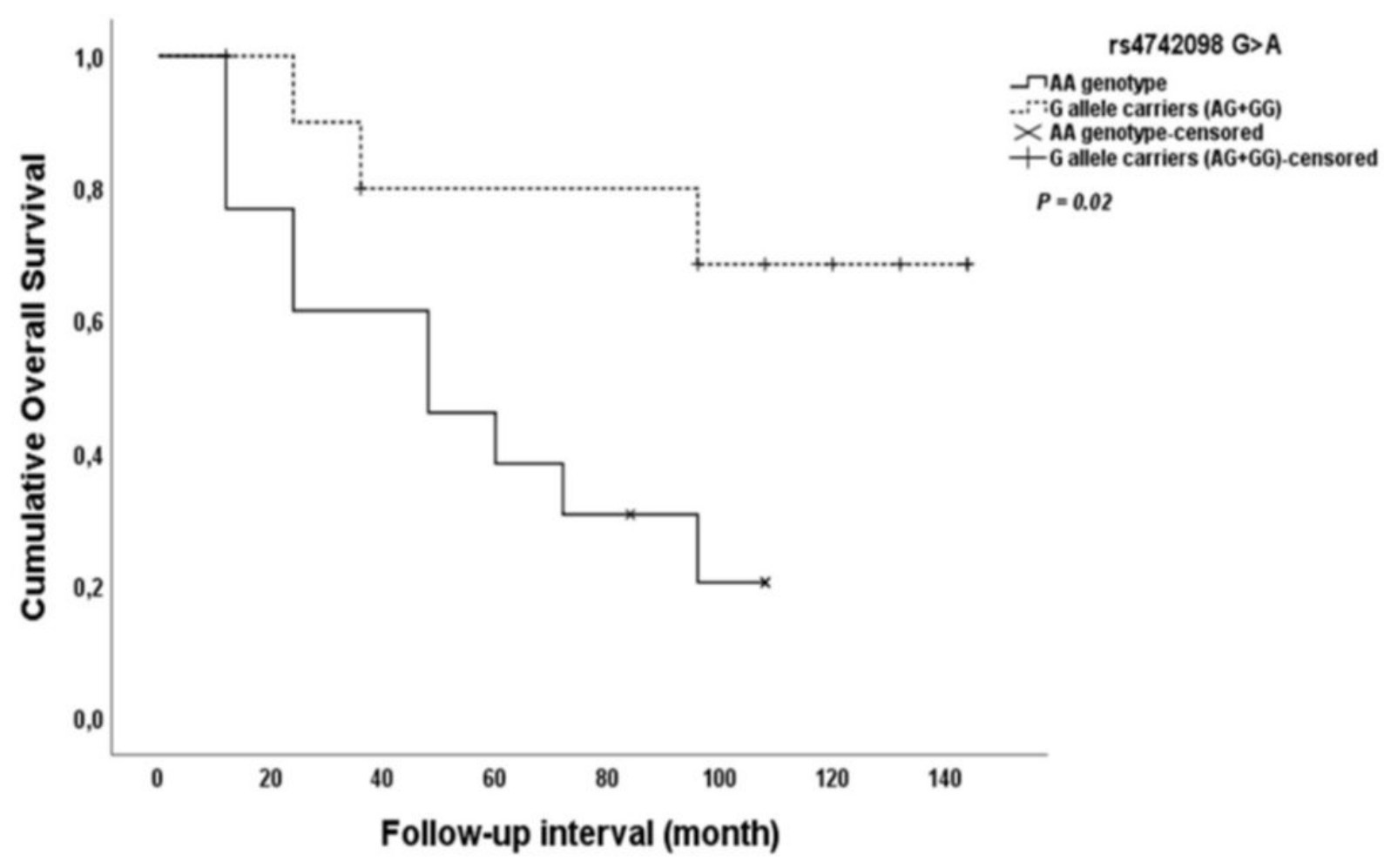

\begin{tabular}{|lccccc|}
\hline PD-L1 polymorphisms & \multicolumn{2}{c}{ Overall Survival (months) } & $\mathbf{( 9 5 \%}$ CI) & $\begin{array}{c}\text { Chi-Square } \\
\text { (Log Rank) }\end{array}$ & P-value \\
& Mean & $\begin{array}{c}\text { Standard } \\
\text { Error }\end{array}$ & & \\
\hline rs 4742098 G $>\mathbf{A}$ & & & & \\
\hline AA genotype & 56.00 & 10.21 & $(35.97-76.02)$ & 5.25 & $\mathbf{0 . 0 2}$ \\
G allele carriers (AG+GG) & 115.71 & 14.49 & $(87.29-144.13)$ & & \\
\hline
\end{tabular}

\section{Figure 1}

Kaplan-Meier survival curve according to PD-L1 rs4742098 G>A. Patients that were G allele carriers (AG+GG) had a higher survival rate compared to those who were AA genotype of rs4742098 $(P=0.02)$. 


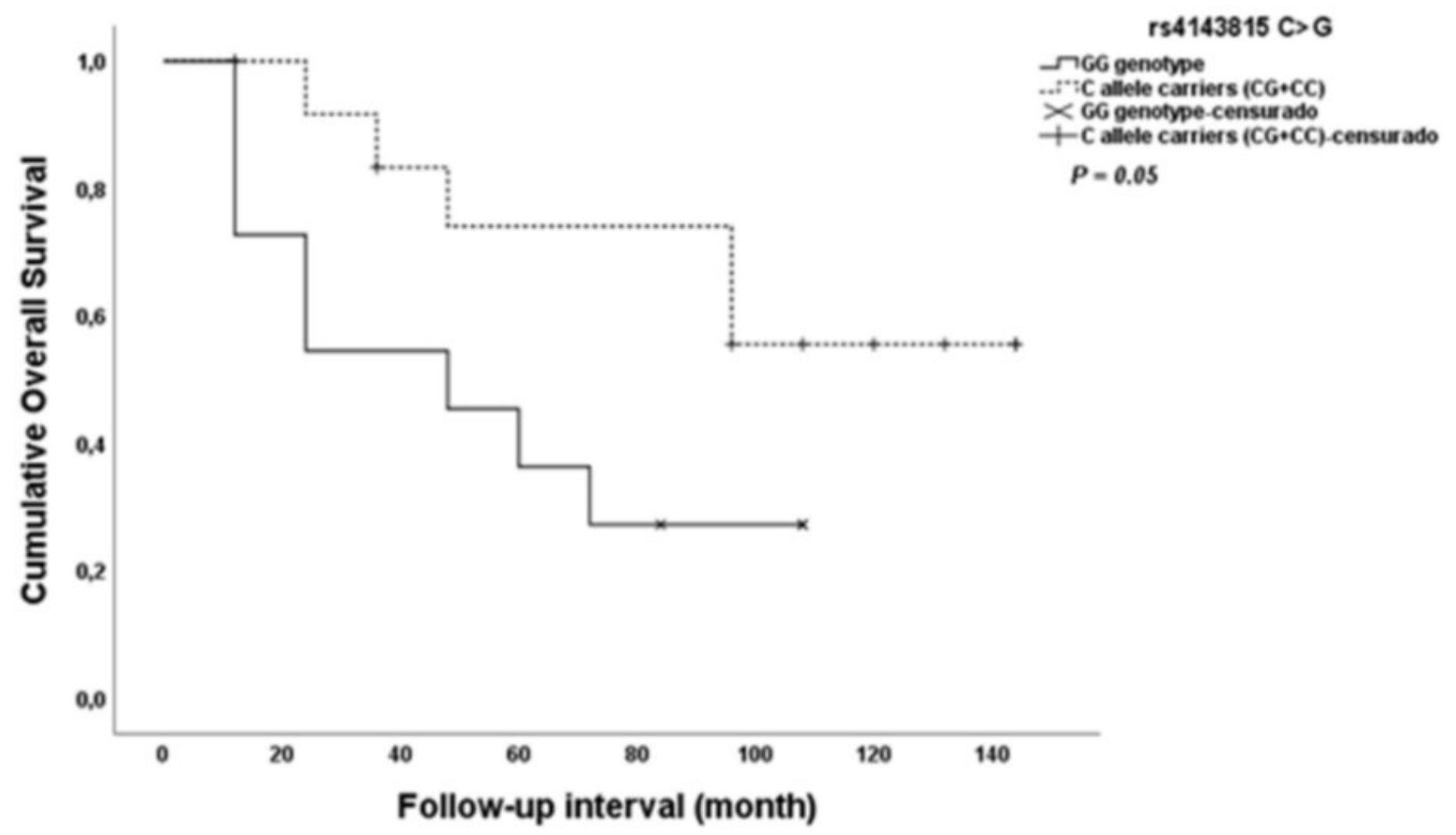

\begin{tabular}{|c|c|c|c|c|c|}
\hline \multirow[t]{2}{*}{ PD-L1 polymorphisms } & \multicolumn{2}{|c|}{ Overall Survival (months) } & \multirow[t]{2}{*}{$(95 \% \mathrm{CI})$} & \multirow[t]{2}{*}{$\begin{array}{l}\text { Chi-Square } \\
\text { (Log Rank) }\end{array}$} & \multirow[t]{2}{*}{$P$-value } \\
\hline & Mean & $\begin{array}{l}\text { Standard } \\
\text { Error }\end{array}$ & & & \\
\hline \multicolumn{6}{|l|}{ rs $4143815 C>G$} \\
\hline GG genotype & 53.45 & 11.58 & $(30.75-76.15)$ & 3.76 & 0.05 \\
\hline $\mathrm{C}$ allele carriers $(\mathrm{CG}+\mathrm{CC})$ & 107.22 & 13.53 & $(80.68-133.75)$ & & \\
\hline
\end{tabular}

\section{Figure 2}

Kaplan-Meier survival curve according to PD-L1 rs4143815 C>G. Patients that were $\mathrm{C}$ allele carriers $(\mathrm{GG}+\mathrm{CC})$ had a higher survival rate compared to those who were GG genotype of rs4143815 ( $P=0.05)$. 


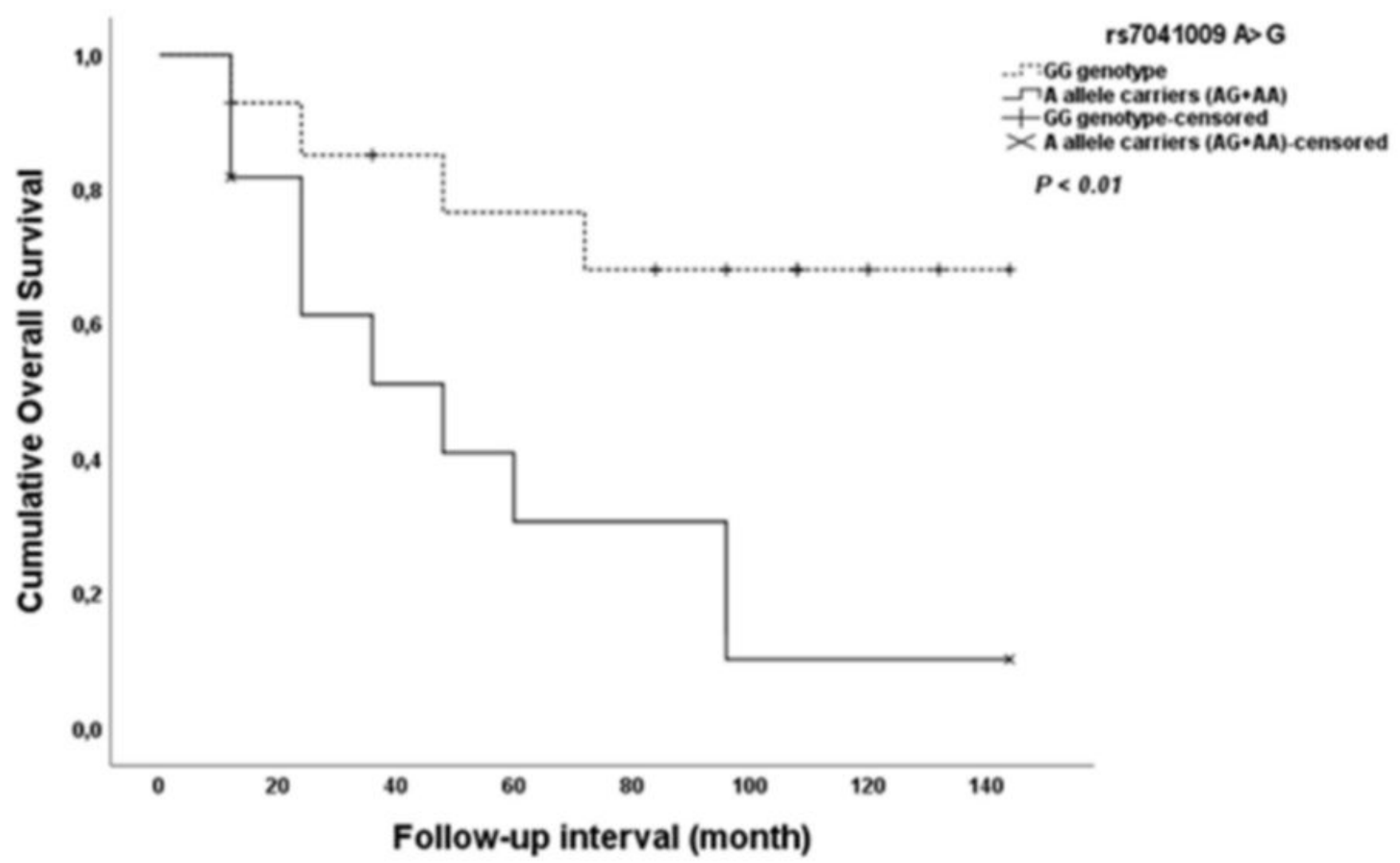

\begin{tabular}{|c|c|c|c|c|c|}
\hline \multirow[t]{2}{*}{$P D-L 1$ polymorphisms } & \multicolumn{2}{|c|}{ Overall Survival (months) } & \multirow[t]{2}{*}{$(95 \%$ CI) } & \multirow{2}{*}{$\begin{array}{l}\text { Chi-Square } \\
\text { (Log Rank) }\end{array}$} & \multirow[t]{2}{*}{$P$-value } \\
\hline & Mean & $\begin{array}{c}\text { Standard } \\
\text { Error }\end{array}$ & & & \\
\hline \multicolumn{6}{|l|}{ rs $7041009 \mathrm{~A}>\mathrm{G}$} \\
\hline GG genotype & 110.98 & 14.00 & $(83.53-138.43)$ & 6.76 & $<0.01$ \\
\hline$A$ allele carriers $(A G+A A)$ & 56.18 & 13.11 & $(30.47-81.88)$ & & \\
\hline
\end{tabular}

Figure 3

Kaplan-Meier survival curve according to PD-L1 rs7041009 A>G. Patients that were A allele carriers (AG+AA) presented worse prognosis with lower survival rate when compared to those who were GG genotype of rs7041009 $(P<0.01)$.

\section{Supplementary Files}

This is a list of supplementary files associated with this preprint. Click to download.

- SupplementaryTable2.docx

- Supplementarytable1.docx 